\title{
Managing Nigeria's development through the public budget: Lessons from the foundations laid by Okotie-Eboh, 1958-1965
}

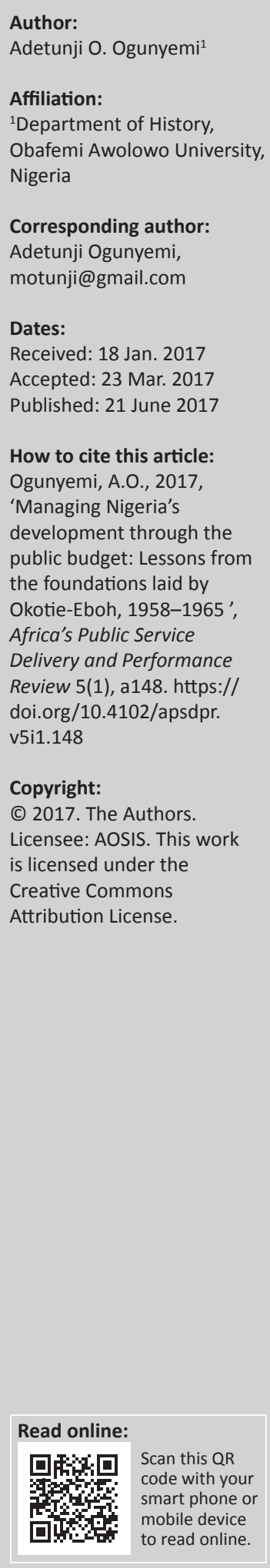

\begin{abstract}
This article examines the essential issues in the economic development of Nigeria in the 1960s as shown in all the budget speeches presented to the parliament by her first indigenous Finance Minister, Festus Okotie-Eboh. The study highlights the Minister's efforts to obtain parliamentary approval for the Appropriation Bills laid by his government before the Nigerian House of Representatives in Lagos. The purpose being to underscore the role of the individual in shaping the course of the development of any nation. Hence, the study identifies the fiscal policy orientation upon which the key programmes and projects reflected in such speeches were built. It also establishes the extent to which the projects were achieved. The study concludes that Chief Okotie-Eboh's parliamentary speeches on Nigeria's federal budget, though loaded with oversized literary niceties, were still, rather than depictive of a mere display of endless parliamentary filibustering, indeed, a veritable part of the sources of Nigeria's public history.
\end{abstract}

\section{Introduction}

In 1957, Nigeria was still a vassal of Britain, but plans had begun by then to reach concluding stages in the decision to decolonise the country and to hand over her control to the indigenous elite. Thus, in September of that year and after a series of constitutional conferences and amendments to the 1954 Oliver Lyttleton Constitution, British authorities agreed to an election to produce the leaders that would lead Nigeria to independence (Udoma 1994:142). The election was conducted and Alhaji Abubakar Tafawa Balewa of the Northern People's Congress (NPC) whose party had won the largest number of seats in the Nigerian House of Representatives was appointed as the Prime Minister of Nigeria. The Cabinet which Sir Balewa put together had a total of 13 Ministers, one of whom was Chief Festus Samuel Okotie-Eboh. Chief Okotie-Eboh was assigned the portfolio of the Ministry of Finance. He, by that appointment, became Nigeria's first indigenous Minister in charge of federal finance.

Chief Okotie-Eboh was not a stranger to Nigeria's political and economic spaces. He had originally been a member of the National Council for Nigeria and the Cameroons (NCNC), under the leadership of Dr Nnamdi Azikiwe (Ige 1995:6, 15). The conservatives were bent on taking over political power from the British and preventing their more aggressive and radical opposition leaders such as Chief Obafemi Awolowo of the Action Group, Mr. J.S. Tarka of the United Middle Belt Congress (UMBC) and Mallam Aminu Kano of the Northern Elements Progressive Union (NEPU) from upstaging the established capitalists' interests in the country (Coleman 1958:356, 358).

The Nigerian legislature was unicameral in the decolonisation period. It consisted only of the House of Representatives which met in Lagos, the then capital of Nigeria. There were three major political parties then: the NPC, NCNC and the AG (Action Group). But no one party dominated the House, although it was clear that the NPC/NCNC alliance was strong enough to guarantee a stable polity (Ige 1995:137). However, the three major political parties of the NPC, NCNC and AG were ably represented by some of Nigeria's best men. These were men who were superbly grounded in grassroots mobilisation, manifesto articulation and the nitty-gritty of parliamentary etiquette. The AG was extremely strong as the party which produced the leader of the opposition. It engaged, constantly, the ruling alliance in some of the most astute debates in Nigeria's legislative history, leaving no one in doubt that it was prepared to discharge its role as a veritable opposition party. 
The NPC/NCNC alliance was no pushover either. Occasions occurred in which, for inability to get its will done as a result of the majority support the alliance had in the House, members of the opposition had to stage several walk-outs on the leadership of the House (Olusanya 1980:536). Very little was gained though by this. But it nonetheless sent signals to the ruling alliance that it needed to convince the opposition by strong arguments and superior rationality if it wanted a stable polity that could be kept at peace with itself. Hence, parliamentarians invested much effort in how they presented and argued their motions. No single motion or bill passed without very testy debates. But the most enervating of such debates always came to the fore when money bills of which budgets or Annual Appropriation Acts were the most significant were laid before the House. Thus, the Minister of Finance had to, using reasonable argument supported by facts and figures, convince his co-parliamentarians of the need for them to approve his expenditure and revenue estimates.

\section{Nigeria's fiscal policy orientation under Chief Okotie-Eboh}

As it is today in Nigeria, where Finance Ministers formulate clearly delineated fiscal policies aimed at charting for their governments good financial courses for development, so it was in the period when Chief Okotie-Eboh was Minister of Finance. He enunciated and pursued a number of fiscal policies which he considered very central to Nigeria's economic development and all of these were encapsulated in his budget speeches. The most commonly restated of such policies was the rapid expansion in the infrastructural base of the country. The Minister showed that Nigeria needed to quickly expand critical infrastructure such as railways, electricity and schools. The arrowheads of all these infrastructures were: Niger Bridge, Niger Dam, Nigeria Airways and several ports and harbours in Lagos and in the Benin and the Escravos Rivers. Hence, Chief Okotie-Eboh's period of service as Nigeria's Minister of Finance was characterised by an unprecedented expansionary fiscal policy. He encouraged his government to borrow liberally from Western countries and even from the domestic money market, which he founded, to finance plans of a huge expansion in and maintenance of critical developmental infrastructure. He had, in 1958, justified the urgent need for Nigeria's rapid economic development in the following words:
Gone are the days when Nigeria's budget speech was merely a recital of the proposals in the revenue and expenditure estimates a simple balancing of government's domestic accounts. Today, as we stand on the threshold of independent nationhood, we have already taken full command of our own financial fortunes. We have to evolve our own policies for the conduct of our economic and financial affairs. (Okotie-Eboh 1960:1)

The Minister's speeches in parliament were always directed at either how to borrow more money in pursuit of new projects or how to launch new projects that would require more expenditure demands on the public treasury (Okotie-Eboh 1963). He always ran into stormy debates and trenchant criticisms from the opposition on these issues. His budget speeches therefore oscillated, essentially, between how to pacify the opposition to permit more taxes to be levied to secure more revenues and how to convince even his own party and the ruling alliance that the aggressive expenditure he had planned would not overheat the economic system and cause inflation.

\section{The essential features and tenor of Okotie-Eboh's speeches}

Chief Okotie-Eboh's parliamentary speeches covered a wide range of areas on the country's economic trajectory. But the most significant were those on taxation and federally collected revenue, smuggling and its negative effects on the economy, petroleum production, export and development, fiscal and absorptive capacity of the economy, foreign and domestic borrowings and the issues of infrastructure development. The Minister was also fond of interspersing his budget speeches with several quotations from different literary and philosophical genres including, at times, references to some biblical passages. Judging by those speeches, the Minister was not oblivious of the country's exact needs for economic development. He made a total of eight (8) parliamentary speeches on the federal budget, all of which reflected his deep knowledge of the requirements of such needs. The titles of the speeches and the fiscal years to which they related are as shown in Table 1.

\section{His dream for Nigeria's development}

Chief Okotie-Eboh was a consummate dreamer of an economically developed Nigeria. He described the period of his service as Nigeria's Finance Minister as 'the period to

TABLE 1: Federal government budgets presented by Chief Okotie-Eboh, 1958-1965.

\begin{tabular}{|c|c|c|c|c|}
\hline $\mathrm{S} / \mathrm{N}$ & Fiscal year & Title of budget & $\begin{array}{l}\text { Estimated expenditure } \\
\text { (f million) }\end{array}$ & $\begin{array}{l}\text { Actual expenditure } \\
\text { (f million) }\end{array}$ \\
\hline 1 & $1958 / 59$ & 'The People's Budget' & 74267980 & 103493262 \\
\hline 2 & $1959 / 60$ & 'The Responsibility Budget' & 83339560 & 117579168 \\
\hline 3 & $1960 / 61$ & 'The Stability Budget' & 80604360 & 108710000 \\
\hline 4 & $1961 / 62$ & 'The Sovereignty Budget' & 88904280 & 136500214 \\
\hline 5 & $1962 / 63$ & 'The Mobilization Budget' & 98800700 & 152803055 \\
\hline 6 & $1963 / 64$ & 'The Modernization Budget' & 109463180 & 169466470 \\
\hline 7 & $1964 / 65$ & 'The Development Budget' & 140188000 & 191970686 \\
\hline 8 & $1965 / 66$ & 'The Consolidation Budget' & 152436000 & 214360935 \\
\hline Total & & & 828004060 & 1353340730 \\
\hline
\end{tabular}

Source: Federal Government of Nigeria, The Six Budget Speeches of the Hon. F. S. Okotie-Eboh, Ministry of Finance, Lagos; A.O. Ogunyemi, 'Federal Budgets in Nigeria, 1954-1999: A History of the Processes, Policies and Problems', University of Lagos PhD Thesis, 2008:181 
launch Nigeria into its economic "take-off"' stage (OkotieEboh 1962:45; Rostow 1960). Hence, he told his coparliamentarians in 1959 of a dream and vision he had of Nigeria: 'A vision of the new Nigeria, which we have all striven so long to create, prepared as a bride adorned for her husband' (Okotie-Eboh 1959:23). That also explains why he professed rather effusively, three years later, in 1962, his belief in what he called:

A Nigeria whose blood is virile and whose aspirations are fired by noble objectives. The sleeping giant of Africa is awake and determined to take her rightful place marching with the rest of humanity! I have faith in Nigeria, I have faith in our people and, above all, I have faith in this Government and this parliament. (Okotie-Eboh 1962:45)

Chief Okotie-Eboh said these things in March 1962, less than two years after Nigeria became independent. But before that he had to construct a blueprint or a roadmap for Nigeria's fiscal administration. He was faced with the challenge of having to devise a roadmap for matching his words with actions. The roadmap came in the form of the fiscal policies that he proffered for guiding the financial management of the government under Sir Balewa.

It should be mentioned that at the dawn of independence, Nigeria's federal budget had an even balance of expenditure and revenue. That is, what the country spent on its services and purchases, in most cases, was equal to what she earned as revenue. That was the colonial fiscal orientation that Sir Balewa's government inherited. In other words, the fiscal policy of the preceding colonial government was very cautious, if not decidedly contractionary (Ihimodu 1994; Lawal 1979; Ogunyemi 2011:37). But with the full takeover of the reins of political leadership in October 1960, Sir Balewa's government became free to enunciate its own fiscal policy framework for the determination of both its expenditure and revenue generation orientations. Balancing revenue with expenditure was not the primary concern of Sir Balewa's government but developing the economic infrastructure of the country. The task of evolving a policy framework that would bring about such a development therefore fell on the shoulders of Chief Okotie-Eboh, as the government's Finance Minister. Hence, the Minister came up with a 10 point fiscal policy framework in March, 1960, which defined the tenor and direction of the government's budgetary processes and expenditure orientation. The 10 point policy, which he crafted in what arguably were some of the most outstanding budget speeches delivered on the floor of the Nigerian House of Representatives, was enumerated as the: (1) maintenance of confidence in the value of the Nigerian currency and the maintenance of reasonable stability in wages and prices, (2) expansion of basic infrastructure, (3) increased public expenditure support to agricultural production, (4) encouragement of industrial production and the development of mineral resources, (5) promotion of Nigerian manpower training, (6) direction of development works in accordance with importance to Nigeria and the coordination of the activities of all the government in the federation to achieve this, (7) arranging for the provision of development funds from both domestic and overseas sources, (8) continued development of the social amenities required for development factoring into it the capacity of the economy to sustain them, (9) ensuring that Nigeria plays her full part in the international institutions and organisations designed to promote development and freer and wider international trade and (10) ensuring that Nigeria plays her full part, both as a donor and a recipient, in international technical assistance programmes (Okotie-Eboh 1960:14-15).

Thus, laying the ground rules both for the implementation of the policies enunciated above and the consolidation of the gains arising therefrom in all parts of the country became the responsibility of the Federal Ministry of Finance under Chief Okotie-Eboh. In the first five years of Nigeria's independence, clear evidences from her macroeconomic conditions showed that the country was in dire need of development finance. Her developmental needs, defined in terms of basic infrastructure such as roads, rail, schools, clinics and skilled man power were grossly inadequately met (IBRD 1954:10, 40-41). So, what Chief Okotie-Eboh did was to appeal first to the country's development partners abroad for loans, gifts and donations of such a quantum as would be fairly adequate for the needs of the country. His achievement in this regard was not as significant as the Development Plan in the period had envisaged. Only about $£ 8$ million out of the $£ 50$ million promised by the partners representing just $16 \%$ of the sum ever was received from them (FRN 1964:3). He therefore had to turn to domestic sources for support.

\section{Issues of revenue, taxation and the federal treasury Taxation and federal revenue}

The fiscal operation of Sir Balewa's government was not as smooth as its apparent success in the search for and the securing of loans would suggest. In fact, the budgetary process and the revenue profile of the government were so bedevilled by persistent problems of revenue shortages, among others, that the Minister of Finance had to report publicly his frustration on the floor of the House of Representatives in March 1962 while presenting his 'Mobilisation Budget' in the year. He complained of the utter difficulty encountered in levying and collecting taxes from business people in Lagos especially, and the seemingly organised attempt at tax evasion in every other part of the country. He lamented:

If a man, or a woman, has a separate source of income, that income is taxable, and the appropriate income rate will be charged. If there is no income, income rate is not charged. It was, Sir, a source of considerable surprise and disappointment to me to learn a few weeks ago that there had been a march of women on the offices of the Federal Board of Inland Revenue to complain about the collection of income rate from women....This policy is quite clear and specific, all residents of the Federal Territory, regardless of their sex, must contribute a fair share to the revenue through the income rate, each individual's share depending solely upon the existence of a source of income and on the size of that income. (Okotie-Eboh 1962:35) 
This shows that one of the most serious problems of Nigeria's public finance during the tenure of the Minister was either tax evasion or tax avoidance. Government had to fight constant battles, literally, to keep its tax policy of equitable levy on virtually all taxable items under federal jurisdiction afloat. In the very year that Chief Okotie-Eboh presented his first budget document to the House of Representatives in 1958, tax evasion was one of the most debilitating problems of federal finance that he mentioned. He said:

And yet tax evasion still goes on with the result that the dishonest benefit at the expense of the honest. So, I appeal to our fellow countrymen to give us their wholehearted support in stamping out this practice which has eaten deep into the economic heart of our beloved country. I ask all of you here in this House and I call on that much wider public which follows our deliberations in this House to let the truth be known. Let everybody know that by evading tax the culprit is defrauding not 'the Government' but the whole Nigerian community. (Okotie-Eboh 1958:3)

\section{Borrowing for capital development}

The Minister gave a picture of the financial needs of the country as early as March 1959, after a survey of the budgetary needs for the expansion of basic infrastructure, in this manner:

Within the last few days, my colleagues in the Regions and the Southern Cameroons and I have completed an assessment of our overall requirements for additional finance to meet the cost of our development programmes. The total cost of all these programmes taken together exceeds the available resources by no less than $£ 58.1$ million. This very large gap can only be filled if we are to utilize to the full, all the possibilities open to us. (Okotie-Eboh 1959:19)

If there was any justification for the Minister's aggressive search for development assistance in the form of loan money, the requirement of numbers 3,4 and 7 of his fiscal policies shown above provided it. For example, the identified policies required that the government, both at the Federal and Regional levels expanded basic infrastructure, public expenditure on agricultural production and secured development funds from both domestic and foreign sources. These were clearly expensive ventures that were unmistakably expansionary in terms of spending and securing revenue generation sources. The rate and the level of the expansion was such that Nigeria's public resources could not provide for it alone; there had to be a recourse to both foreign and domestic borrowings.

One of the possibilities that opened to the government was borrowing from domestic sources. The Nigerian money market was born as a result of this. Hence, the market which was first begun through the sale of government securities, development loan bonds and treasury bills provided the federal government significant financial resources that she needed before 1966. Therefore, in the fiscal years 1959/60, 1960/61, 1961/62 and 1962/63, the federal government borrowed from domestic sources the total sum of $£ 171419647$ million. The progressive build-up of such loans and financial instruments from 1959 to 1963 is as shown in Table 2.
TABLE 2: Domestic loans received by the Nigerian government, 1959/ 60-1962/63.

\begin{tabular}{lll}
\hline Fiscal year & Amount ( $\mathbf{f}$ million) & Loan instrument \\
\hline $1959 / 60$ & 2355360 & Treasury bills \\
$1960 / 61$ & 43569129 & Treasury bills \\
$1961 / 62$ & 58129614 & Treasury bills \\
$1962 / 63$ & 67365544 & CBN bonds \\
\hline Total & 171419647 & Bills \& bonds \\
\hline
\end{tabular}

Source: Reports of the Accountant General of the Federation Together with Financial Statements, 1960-64. Government Printer, Lagos, 1964

$\mathrm{CBN}$, Central Bank of Nigeria.

Throughout the period 1958-1966, Chief Okotie-Eboh embarked on numerous foreign trips to seek development assistance for the country. His declared philosophical premise in this regard, apart from his usual refrain 'value for money', was as defined by the ideas of George Bernard Shaw, who was quoted by the Minister to have said that: 'Money is indeed the most important thing in the world, and all sound and successful personal and national morality should have this fact for its basis' (FRN 1958:7). In addition, Chief OkotieEboh had justified his personal conviction on the need to borrow on the grounds of the urgent imperative of raising the standard of living of the ordinary Nigerian. He said:

The achievement and maintenance of the highest possible rate of increase in the standard of living and the creation of the necessary conditions to this end, including public support and awareness of both the potentialities that exist and the sacrifices that will be required. (FRN 1960:14)

\section{Budgetary expenditure and revenue balance}

However, it was not only the revenue of the government that was confronted with dire challenges. The expenditure account of the government too had its own debilitating challenges. In fact, the problems that bedevilled the country's expenditure profile were almost as serious as those of smuggling, tax evasion and tax avoidance. In particular, there were, up to 1963, the problems of 'under-expenditure' due to considerable lack of adequate absorptive capacity within the economy. Nigeria, being a very young economy in the late 1950s up to the early 1960s, suffered from lack of absorptive capacity (FRN 1958:8). There was also the problem of inadequate executive capacity even where there were surplus funds to prosecute government projects. The lack of executive capacity was due to the dearth of skilled professional and adequate technical class of civil servants who could help initiate, direct and monitor the government expenditure on critical infrastructure projects. On the problem of under-expenditure occasioned by the deficit in absorptive capacity, especially for the capital budgets of the fiscal years 1957/58-1962/63, the Minister of Finance lamented:

As far as the capital budget is concerned, the latest estimates of expenditure for 1957/58 show that once again we must expect very considerable under-expenditure and, as I have mentioned earlier, the reasons for this are at present being examined by the Economic Adviser ... in the light of past performance, it may well be asked what purpose is served by making provision of $£ 361 \frac{1}{2}$ million in next year's capital estimates when it is likely that there will be considerable under-expenditure? (FRN 1958:8) 
In other words, the expenditure situation during Nigeria's First Republic shown in the quotation above contrasts very sharply with the contemporary expenditure situation and orientation of the government. In the last 13 years of civil democratic rule, for example, rather than have a situation of under-expenditure, what the government always had was considerable over-expenditure, leading to huge deficits in the federal government account and a disconnect between expenditure and revenue profiles (Ogunyemi 2012, 187).

\section{Emergence of petroleum revenue}

Some few months after Chief Okotie-Eboh took over as Finance Minister, a breakthrough in the petroleum industry, which had only begun to get public and private attention in 1955, was recorded (FRN 1959:8). In his budget speech for the 1958/59 fiscal year, the Minister enthused: 'on the 17th day of February, 1958, after years of intensive effort at a cost to date of some $£ 40$ million, the first commercial shipment of Nigerian oil left our shores' (FRN 1959:8). But the enthusiasm of the Minister did not blind him to the need to immediately begin to carve out a formula for the levying of taxes on petroleum profit. Therefore, he added, 'I hope to present to this House a Bill to provide for the taxation of companies engaged in mineral oil production on the 50:50 basis which is a feature of such arrangements in many other countries, including Ghana' (FRN 1959:8, 9).

It has been shown that petroleum export brought into the treasury of Nigeria in the first year of its export (1958), the sum of $£ 48000$, representing $0.06 \%$ of total federally collected revenue in that year (FGN 1959:2). It is important to stress here that petroleum export, which accounts for between $70 \%$ and $80 \%$ of Nigeria's external receipts today was an insignificant revenue source to Nigeria from 1958 to 1968. In those years it accounted for, on average, less than $5 \%$ of total federally collected revenue (Ogunyemi 2011:42). Revenue from oil export became significant for the first time in the $1969 / 70$ fiscal year when it was $15.9 \%$ of federally collected revenue (Ogunyemi 2011:46). Just two years later, in 1972, it surpassed contributions from the Customs and Excise revenue (which had always been the lead revenue earner since 1900) when it accounted for a whopping 54\% of federally collected revenue (CBN 2000:92). Since the latter date, revenue from oil export has taken the lead with an unbroken record to date as the largest revenue earner for the Federation of Nigeria.

\section{Challenges of Nigeria's federal finance}

\section{Inadequate absorptive and executive capacity}

Yet, even if the government of the First Republic had planned for and actually did release money for federal projects, there was the rather delimiting factor of inadequate executive capacity to supervise its utilisation. This problem, among other equally serious ones, accounted for the slow pace at which the government worked to overcome the problem of the non-implementation of a substantial portion of its capital budget. Chief Okotie-Eboh complained that the problem accounted for the extension of the lifespan of the first indigenously designed National Economic Development Plan, which was scheduled to last from 1955 to 1960 but which had to be extended by two years, to 1962. Chief OkotieEboh identified inadequate executive capacity as serious enough to derail his plan for infrastructure development when he complained to the parliament, in 1958, thus:

In addition, however, the serious lack of executive capacity particularly on the part of the Public Works Department has aggravated the position and my colleagues and I therefore decided that in order to carry out a realistic review, we should assume that the life of the present programme would extend until 1962. (FRN 1958:9-10)

The measures directed at solving the inadequate executive capacity problem soon bore good fruits and very quickly too. The government embarked on a massive intervention measure of training some selected Nigerians from the public service who were sent on government bills to the University College, Ibadan, and overseas tertiary institutions. This was done via the Federal Government Scholarship Scheme instituted by the Sir Balewa government (FGN 1964:187-188, 209-210). The measures were successful because of the government's very aggressive policy of awarding scholarships to as many Nigerians as qualified under the scholarship programme to acquire university education both at the University College, Ibadan, and overseas. Many of those who won the scholarship joined the Federal Civil Service after their graduation, thereby increasing its pool of skilled and highly trained professional employees that could help drive the machinery of state. Thus, Chief Okotie-Eboh announced in 1960, barely two years after he lamented the debility which the problem of inadequate executive capacity brought on federal finances, that Nigeria had overcome the problem. The announcement was made while delivering his 1960/61 budget speech in the parliament in Lagos, in February, 1960. He said, 'Executive capacity is no longer the problem. It is financing the programme which is going to give us the headaches from now on' (FRN 1960:32).

Still, one of the ironies of the contending issues in Nigeria's finances in the late 1950s up to 1965 was that while the government complained on the one hand of considerable under-expenditure in its budgetary performances, there was, simultaneously, on the other hand, complaints of 'resource shortages' (FRN 1958:3, 4, 9, 1959:19, 20, 1960:3, 7). It cannot cease to baffle one why a government would complain that it could not, due to several reasons, spend all that it had budgeted and, at the same time, complain of not having enough money to spend on its projects. But such a contradiction has been shown to be true of Nigeria's financial history even before 1966 (Ogunyemi 2011). Between 1957 when Chief Okotie-Eboh took over as Finance Minister and January 1966 when he was murdered, Nigeria practically struggled to secure loans for the financing of every infrastructure project identified as key to her development - railway, electricity, air transport, Niger Dam, Niger Bridge, etc. (Ademoyega 1981:112; FRN 1965). Her 
budgetary under-expenditure was not due to the absence of projects on which the unspent funds could be expended but to gross shortages in executive capacity to initiate, supervise and implement heads of expenditure in the federal budget.

Hence, when the problems of executive capacity shortages were solved beginning in the 1960/61 fiscal year, the problem of resource shortages in terms of investment specie became more obvious. The Minister had to resort to borrowing from domestic and foreign creditors. But most of Nigeria's foreign development partners were not forthcoming in giving loans to the country being fearful of the possibility of losing their investment, since Nigeria, by the 1960s, was still an untested partner in international finance, at least under indigenous leadership. Hence, very little funding as we have earlier shown came from them. In order to surmount this problem, Chief Okotie-Eboh had to fall back on domestic sources and as this too was not yet sufficiently developed even in the late 1950s; he had to build it from scratch.

First, the Minister saw the need to create an institution that would be financially autochthonous and under indigenous control to direct both the monetary and fiscal policies of Nigeria. Therefore, in 1958, he took steps to encourage the creation of the Central Bank of Nigeria (CBN), which he, at first, entrusted in the hands of the British renowned financial expert, Mr R.P. Fenton, as Governor. It was Mr Fenton and, later on, AlhajiAliyu Mai-Bornu who pioneered the development of the Bank and opened it for operation for the first time in October, 1959 (CBN 1999:3; FRN 1960:3). After this, the Bank floated government bonds and treasury bills, the proceeds of which were used in the financing of public projects.

\section{Smuggling}

Smuggling too, was a cause of worry for Chief Okotie-Eboh. Smuggling, anywhere in the world, is a kind of tax evasion since smugglers import goods into a country without paying the required duties on them. It is also a way by which unscrupulous elements may import prohibited goods such as narcotics, arms and toxic wastes into a country by either compromising law enforcement agents through bribery or even violently attacking them in order to secure an unhindered passage for their contrabands. Smuggling was particularly injurious to Nigeria's nascent economy in the 1960s because the country was just emerging from colonialism and she needed every shilling she could get from all legitimate means possible. But smugglers compromised this, leading to huge revenue losses particularly along the Seme and IdiIrokoborders in the Western Region, from where innumerable consignments of contraband escaped appropriate levies and duties (FRN 1962:35).

Thus, in his 1961 budget speech, Chief Okotie-Eboh, under whose direct control the Department of Customs and Excise fell, complained vociferously on the helplessness of the Department in curbing smuggling with its attendant consequences on Nigeria's revenue pool. He said:
One particular problem which concerns me is the steady flow of smuggled goods, particularly brandy from the Island of Fernando Po. Last year I visited the capital, Santa Isabel, and held discussions with the Spanish authorities. The results of these discussions are being examined and it is my hope that it will not be long before we can effect a marked reduction in this heavy trade in contraband between the Island and Nigeria. (FRN 1960:30, 1962:35)

Despite the intervention of the Minister and the promise by the Spanish authorities in Fernando Po (now Equatorial Guinea) to cooperate with Nigeria in checking the activities of smugglers who operated from their territory, exporting contraband to Nigeria, the illegal trade continued. For example, in his 1962 address to the House of Representatives on the Federal Budget for the year, Chief Okotie-Eboh still complained of this same problem and went further to give the House the statistical enormity and significance of the smuggling activity:

Last year, over ten million cigarettes, twenty-two thousand pounds of tobacco, thirty-five thousand bottles of spirits and other goods totalling twenty-four thousand pounds in value were seized by Customs, Navy and Police patrols on land and sea ... yet, impressive as these figures are, they represent a small fraction of the smuggled goods reaching our markets from Fernando Po and, to a much lesser extent, from other neighbouring countries. The effect on the economy of this country is serious, for we lose in many ways. Firstly, there is the heavy loss of revenue on brandy, cigarettes, tobacco and drugs which are illegally imported ... second, there is a loss of export duty on palm produce and also a loss of produce purchase tax to the Eastern Region. Thirdly, there is a loss of foreign exchange by the sale of palm produce for pesetas and the use of the latter to purchase contraband. (FRN 1962:35-36)

\section{Building critical physical and financial infrastructure Physical infrastructure}

Huge public projects built by the government of Sir Balewa under the supervision of its Finance Minister were many. Six of such notable projects and physical infrastructure were: (1) Niger Bridge from Asaba to Onitsha, (2) Niger Dam at Kainji, (3) railway extension from Jos to Borno via Bauchi, (4) Nkalagu Cement Factory, (5) the Second Lagos Bridge and (6) the construction of the Escravos Bar and Jetty. For the Niger Bridge project, Chief Okotie-Eboh had to negotiate a contract agreement with the main contractor to spread the payment for the project over a period of 10 years ending in 1968. The bridge was built at the financial cost of $£ 42$ million (FRN 1959:23). The Minister noted that the type of contractor finance was a: 'New development for Nigeria although it is extensively used in several other parts of the world. My colleagues and I are at present considering specific proposals of this nature in connection with the Second Lagos Bridge.' (FRN 1961:2).

It is important to show that apart from the Niger Bridge referred to above, between April 1959 and March, 1962, Chief Okotie-Eboh negotiated for and secured loans in executing 
six other important capital projects in different parts of the county. These were: (1) a General Hospital in Lagos, (2) dredging of parts of Nigeria's inland waterways in Lokoja and Baro, (3) construction of the Koko Port, (4) a low-cost housing estate in Obalende, Lagos, (5) Second Lagos Mainland Bridge and (6) land reclamation in Victoria Island, Lagos. All these projects cost the federal government a total of $£ 102.25$ million (FRN 1960:33; Lawal 1994; Olukoju 2003).

It should be noted that the same method of negotiation which was used to finance the Niger Bridge was brought to bear on the Niger Dam project at Kainji. The Dam was designed not only for hydro-electricity generation but also for irrigation and water supply to its immediate environs in central Nigeria. Chief Okotie-Eboh remarked that the project both in terms of the sums invested and the engineering infrastructure designed to be constructed was unprecedented in Nigeria's public infrastructure history (FRN 1962:2). The feasibility report for the project was completed in February 1958, and the government immediately mobilised contractors to begin work. When work actually began, Chief Okotie-Eboh informed the House of Representatives of the estimated financial cost of the project and its place in Nigeria's Development Plan. He said:

We believe that the corner-stone of the plan will almost certainly be the Niger Dams Project. This, in itself, will be a project of tremendous size and scope, the capital investment involved will be of the order of sixty-seven million pounds. This will make it the biggest single project ever undertaken in Nigeria. (FRN 1961:2)

Again, in March 1961, when the project had begun to be implemented and significant progress recorded, the Minister once against informed the parliament of the state of progress on its construction and the good it was planned to achieve. He enthused:

The greatest single project in the Plan- the Niger-Dam-in many ways epitomises the development of our natural resources in an integrated manner for the benefit of the country as a whole. It will not only provide electricity to all parts of the country for us as an amenity, but also as an important industrial raw material. It will improve the navigation on the main river ways, lowering transport costs and providing easier, as well as cheaper access to the interior from the sea. It will regulate floods and permit agricultural production in areas in all three Regions at present infertile. (FRN 1962:2)

The extension of the railway from the Jos-Bauchi line to Borno was made possible via the International Bank for Reconstruction and Development loan of $£ 10$ million secured on the 2nd of May 1958 (FRN 1959:2). The negotiation for the loan was led by Chief Okotie-Eboh as Finance Minister from March to April of the same year. The Minister referred to the loan as crucial to the railway project even when colonial authorities were yet to completely disengage from the country. The importance of the loan he stressed was 'not only because of the intrinsic value of the loan, but also because of the proof which it gave to the eyes of the world of Nigeria's credit worthiness' (FRN 1959:2). The railway extension project was completed in June of 1961. Added to the list of the capital projects in which the government invested huge sums of money and the importance of which can be glimpsed from the parliamentary speeches of Chief Okotie-Eboh were the Nkalagu Cement Factory and the construction of the Escravos Bar and Jetty in 1959. These two projects were completed in 1961 (FRN 1958:6, 1959:19).

\section{Financial infrastructure}

Prior to the establishment of the CBN, Nigeria's foreign reserves, which, by March 1958, was a whopping $£ 220$ million was held entirely by the West African Currency Board (WACB) on behalf of the federal government (Lawal 1989:140). No Nigerian indigenous institution oversaw or managed the country's monetary interests. Such interests were managed by British owned financial institutions and, as such, they could not be deployed to create money or any independent investment specie for Nigeria. It was, therefore, not surprising that the first task the CBN embarked upon immediately on its commencement of operations in October, 1959, was the issuance of treasury bills which were directed at raising short-term loans for the development of the country. The value of the treasury bills raised in 1959 by the CBN was $£ 4$ million (FGN 1960:7; FRN 1960:3). The Bank also implemented, under the direct supervision of Chief OkotieEboh, the first 'Nigerianisation' policy of the Nigerian currency by changing it from the WACB's pounds to the Nigerian shillings (FRN 1959:10).

In the attempt to 'Nigerianise' Nigerian monetary and investment institutions and then use them to secure investment loans for the country, Chief Okotie-Eboh also established the Lagos Stock Exchange (LSE) (now called the Nigerian Stock Exchange). To him, the exchange was needed to achieve the objective of: 'Nigerianisation of our credit base ... to enable our economy to expand or contract according to our own needs rather than to be forced to accept changes dictated by the needs of some other money market' (FRN 1962:7). Thus, the LSE was intended to, in conjunction with the CBN, serve as a market that could deal not only in government securities and treasury bills but also in the shares of commercial firms. Hence, the LSE was established in 1960 as one of the credit institutions for Nigeria's financial development.

\section{The literary and poetic Okotie-Eboh}

Chief Okotie-Eboh, just like the leader of his party, the NCNC, Dr Nnamdi Azikiwe, has been described as a man who loved the limelight (Ige 1995). He combined this love with oratorical skill which manifested in his penchant for endless filibustering in parliament and in his infinite talent for the dramatic and flamboyant dress styles. His personal apparel and the manner by which he carried himself in public earned him the appellation, which he confessed he loved, 'Omimi Ejoh, Ejoh Bilele', an Itshekiri expression meaning 'the man with long, long features, the flowing wrappers' (Afejuku 2010). Chief Okotie-Eboh had a trademark in 
dressing in long, flattering wrappers, an African buba and a bowler hat to the admiration of his followers but also to the disapproval of his political opponents who saw in the gorgeous dress, a needless, outlandish dress style, if not a wanton display of obscene affluence and showmanship in the face of real poverty suffered at that time by the majority of Nigerians. But rather than being distracted by criticisms of his elaborate apparel, which he wore to the floor of the House of Representatives in Lagos on every day of deliberation, he rather added to it, his literary and oratorical skills reflected in all his budget speeches.

It was customary for him to quote, extensively, several literary scholars and political philosophers in his attempts at driving home his point in parliament. His budget speeches were punctuated by quotes and wise sayings many of whose sources he failed to provide though. Whereas he was denied being a poet, but his actual delivery reflected a man who spent a lot of time reading the classics and the poetry of Western Europe. For example, in his budget speech for the fiscal year 1958/59 (the shortest of his budget speeches, numbering 18 pages), and in an apparent attempt at reminding his colleagues in parliament of the need for them to prepare to shoulder the huge responsibility of independence that Nigeria had begun to plan to receive from Britain, he admonished, rather poetically:

Sir, I am no poet, but I can best express my feelings and at the same time wind up my speech by quoting the words of the greatest playwright of Elizabethan England written at a time when England herself was about to embark on that great expansion which made her the envy of the world:

There is a tide in the affairs of men,

Which taken at the flood, leads on to future,

Omitted, all the voyage of their life

Is bound in shallows and in miseries.

On such a full Sea are we now afloat;

And we must take the current when it serves,

Or lose our ventures. (FRN 1958:13)

The OmimiEjoh had spoken and quoted these words at a time when Nigeria was not very sure, yet, of the extent of the responsibility that would come upon her shoulders as a sovereign state when eventually she became independent of British rule. But they, nonetheless, show his early appreciation of the gigantic task ahead and the need to sensitise his colleagues in parliament to the requirements of those tasks. But it also shows his love for the poetic through his extensive quotation of a literary scholar in a budget speech, which was way off the path of convention in the presentation of money bills even under Commonwealth traditions. Such a long quotation in the budget speech of today's Nigeria would very possibly be regarded as anachronistic, if not utterly unnecessary. It shows the extent to which the Minister could go to convince his colleagues that he had spent much time on poetry.

Again, in his budget speech for the 1959/60 fiscal year, the immediate fiscal year preceding independence, Chief OkotieEboh found it convenient to quote Edmund Burke, the 19thcentury English historian, in an attempt to justify a new regime of taxation he had just introduced in Lagos. He quoted Burke, 'To tax and to please, no more than to love and to be wise, is not given to men' (FRN 1959:24). His new tax regime had attempted to levy property, sales and consumption taxes on all Lagos residents without exception, men and women. The women protested arguing that a taxation on them would amount to double taxation since their 'husbands' were already paying several other taxes (FRN 1962:36). But Chief Okotie-Eboh insisted that such a tax was necessary on the grounds of the exceptional attention paid to the Lagos infrastructure by the federal government and the development of its environment.

Furthermore, words of exhortation always filled Chief Okotie-Eboh's budget speeches. In March 1960, he prayed the House of Representatives to give its utmost in sacrifice for the good of the about to be independent Nigeria. He said, rather emotionally, but again quoting Walter Scott, a 19th century British poet:

Let us therefore, build a society free from want and poverty; and free from the fears of disease. In such a free and happy country, the words of Sir Walter Scott come readily to my mind:

Breathes there the man, with soul so dead,

Who never to himself hath said,

This is my own, my native land! (FRN 1960:34)

When independence was finally assured in March 1960 and Nigeria was just seven months away from the historic event, Chief Okotie-Eboh, again, sounded poetic when he addressed the Speaker of the House of Representatives, on the accounts of the Federation of Nigeria. He enthused:

Sir, with profound sense of how much depends on all of us in Nigeria, may I say with Longfellow:

Thou, too, sail on, O ship of State!

Sail on, O Union, strong and great!

Humanity with all its fears,

With all the hopes of future years,

Is hanging breathless on thy fate. (FRN 1961:36)

In 1963, after the Prime Minister, Sir Balewa, had declared an austerity measure, cutting the salary and other emoluments of himself and all other federal government functionaries, Chief Okotie-Eboh advised Nigerians to save money and to avoid ostentatious living (FGN 1964:36). But in doing that he resorted to the lyrics of a Church hymn the number of which he failed to give. He said:

'It is a mistake to think that one's income is too small and therefore one cannot afford to save anything out of it. Remember the old Church hymn which reads:

Little drops of water,

Little grains of sand,

Make the mighty Ocean,

And the beauteous land.' (FRN 1964:9)

Again, after the crises occasioned by the disagreements among Nigeria's political elites over the 1963 census figures, Chief Okotie-Eboh preached unity, faith and reconciliation on the floor of the House of Representatives urging the opposition to accept the situation as it was. He said: 'Let us therefore go out 
of this House in unity and with faith ... so that each and every one of us can rightly say to himself of our great fatherland, in the words of James, the Duke of Monmouth:
I see in my mind, a noble and puissant
Nigeria rousing herself like a strong
Man after sleep and shaking her
Invincible locks. I see her as an
Eagle mewing her mighty youth, and
Kindling her undazzled eyes at the
Full mid-day beam.' (FRN 1964:25)

In 1965, it was an elated Minister of Finance who declared emphatically the massive success which he adjudged his economic policies to have achieved. In doing this as it was already characteristic of him he was not economical with words and quotations, this time from William Shakespeare. Little did he know that it was going to be his last budget speech on the floor of the House. He enthused: 'The foundations of progress have been laid. Let us now, everyone of us, rededicate ourselves to the task ahead.... In the year to come, let us recall these words of William Shakespeare with which I close my speech (FRN 1965:29):
For so work the honey-bee,
Creature that by a rule in nature teach
The act of order to a peopled kingdom.
They have a king and officers of sorts;
Where some, like magistrates, correct at home,
Others, like merchants, venture trade abroad,
Others, like soldiers, armed in their stings;
Which pillages they will merry march bring home
To the tent-royal of their emperor:
Who, busied in his majesty, surveys
The singing masons building roofs of gold,
The civil citizens kneading up the honey,
The poor mechanic porters crowding in
Their heavy burdens at his narrow gate,
The sad-ey'd justice, with his surly hum,
Delivering o'er to executors pale
The lazy yawning drone.' (FRN 1965:29)

And, he concluded his speech with the usual but mandatory refrain common to the traditions of Commonwealth parliamentary practices: 'Mr Speaker Sir, I beg to move' (FRN 1965:29).

\section{Conclusion}

Chief Festus Samuel Okotie-Eboh was a man of many parts, the most public of which were those of his flamboyant dress style and long, windy speeches in the parliament. But he delivered those speeches in some of the most captivating and fascinating literary styles ever used on the floor of Nigeria's legislature. In the speeches were found the germs of Nigeria's social and economic struggles for the development and the significant landmarks of its infrastructural growth. As the Minister in charge of Nigeria's finance for nine years, his budget speeches contained not only the obvious evidences of Nigeria's revenue and expenditure profiles but also the fundamental economic and institutional factors that conditioned such profiles from 1958 to 1965.

\section{Competing interests}

The authors declare that they have no financial or personal relationships which may have inappropriately influenced them in writing this article.

\section{References}

Ademoyega, A., 1981, Why we struck: The story of the first Nigerian Coup, Evans Brothers (Nigeria Publishers) Limited, Ibadan.

Afejuku, T., 2010, 'Conspiracy against Okotie-Eboh', Nigerian Tribune, 8 November, pp. $1-2$.

Central Bank of Nigeria (CBN). 1999, Statistical Bulletin, 11(2), CBN, Lagos.

Central Bank of Nigeria (CBN), 2000, Statistical Bulletin 11(2), CBN, Lagos.

Coleman, J.S., 1958, Nigeria: Background to nationalism, University of California Press, Berkeley, CA.

Famoroti, F., 2011, 'How Okotie-Eboh's will tore wife, siblings apart,' The Nation, 26 September, p. 1 and 2.

Federal Government of Nigeria (FGN), 1959, Report of the accountant-general of the federation with financial statements for the year ended 31st March, 1959, Ministry of Finance, Lagos.

Federal Government of Nigeria (FGN), 1960, Report of the accountant-general of the federation with financial statements for the year ended 31st March, 1960, Ministry of Finance, Lagos.

Federal Government of Nigeria (FGN), 1963, The budget speeches of the honourable F. S. Okotie-Eboh, Government Printer, Lagos.

Federal Government of Nigeria (FGN), 1964, Mr. Prime Minister: A selection of speeches made by Alhaji the right honourable Abubakar Tafawa Balewa, Prime Minister of the Federal Republic of Nigeria. Ministry of Information, Lagos.

Federal Republic of Nigeria (FRN), 1958, The people's budget, 1958, Government Printer, Lagos.

Federal Republic of Nigeria (FRN), 1959, The responsibility budget, 1959, Government Printer, Lagos.

Federal Republic of Nigeria (FRN), 1960, The stability budget, 1960, Government Printer, Lagos.

Federal Republic of Nigeria (FRN), 1961, The sovereignty budget, 1961, Government Printer, Lagos.

Federal Republic of Nigeria (FRN), 1962, The mobilisation budget, 1962, Government Printer, Lagos.

Federal Republic of Nigeria, 1964, The development budget, 1964, Government Printer, Lagos.

Federal Republic of Nigeria (FRN), 1965, The consolidation budget, Government Printer, Lagos.

IBRD, 1954, The economic development of Nigeria: Report of a mission organised by the International Bank for Reconstruction and Development, IBRD, Washington, DC, pp. 10, 40-41.

Ige, B., 1995, People, politics and politicians of Nigeria, 1940-1979, Heinemann, Ibadan.

Ihimodu, I.I., 1994, 'Nigeria's experience with medium term planning,' in M.I. Obadan \& G.O. Ogiogio (eds.), Planning and budgeting in Nigeria: Institutional and policy reforms, pp. 99-122, NCEMA, Ibadan.

Lawal, A.A., 1979, 'A history of the financial administration of Nigeria, 1900-1945', PhD thesis, University of Lagos.

Lawal, A.A., 1989, 'West African currency board earnings and the distribution of its income, 1912-1945', ODU: A Journal of West African Studies, New Series, 35, 140-160.

Lawal, K. (ed.), 1994, Urban transition in Africa: Aspects of urbanisation and change in Lagos, Pumark, Lagos.

Ogunyemi, A.O., 2011, 'Financing Nigeria's colonial administration: A comparative study of its revenue and expenditure profiles, 1940-1960', Lagos Historical Review $11,37-58$.

Ogunyemi, A.O., 2012, 'Politics of budget making in Nigeria, 1999-2003', African Journal of Economy and Society 11(2), 187-215.

Okotie-Eboh, F. S. 1958, The People's Budget, 1958, Government Printer, Lagos. Okotie-Eboh, F. S. 1959, The Responsibility Budget, 1959, Government Printer, Lagos. Okotie-Eboh, F. S. 1960, The Stability Budget, 1960, Government Printer, Lagos. Okotie-Eboh, F. S. 1962, The Mobilization Budget, 1962, Government Printer, Lagos. Okotie-Eboh, F. S. 1963, The Modernization Budget, 1963, Government Printer, Lagos. Olukoju, A.O., 2003, Infrastructure development and urban facilities in Lagos, 1861-2000, IFRA, Ibadan

Olusanya, G.O. 1980, 'Constitutional development, 1861-1960', in O. Ikime (ed.), Groundwork of Nigerian History, Heinemann Educational Books (Nigeria) Plc, Ibadan, pp. 545-569.

Rostow, W.W., 1960, The stages of economic growth, Oxford University Press, London. Udoma, U., 1994, History and the Law of the Constitution of Nigeria. Malthouse Press Limited, Lagos. 